\title{
Selecting the best and brightest: A comparison of residency match processes in the United States and Canada
}

\author{
EM Krauss MSc MD, M Bezuhly MD MSc FRCSC, JG Williams MD MEd FRCSC
}

EM Krauss, M Bezuhly, JG Williams. Selecting the best and brightest: A comparison of residency match processes in the United States and Canada. Plast Surg 2015;23(4):225-230.

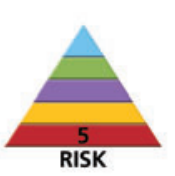

BACKGROUND: Selecting candidates for plastic surgery residency training remains a challenge. In the United States, academic measures (United States Medical Licensing Exam Step I scores, medical school class rank and publications) are used as primary criteria for candidate selection for residency. In contrast, Canadian medical education de-emphasizes academic measures by using a pass-fail grading system. As a result, choosing residents from many qualified applicants may pose a challenge for Canadian programs without objective measures of academic success. METHODS: A 25-question online survey was distributed to program directors of Canadian plastic surgery residency-training programs. Program directors commented on number of yearly residents and applicants; application sections (ranked in importance using a Likert scale); interview invitation and rank-order list determination; and their satisfaction with the selection process.

RESULTS: Ten Canadian plastic surgery program directors responded (90.9\% response rate). The most important application components determining invitation to interview were letters of reference from a plastic surgeon (mean importance of 5.0 on the Likert scale), clinical electives in plastic surgery (mean 4.6) and electives with their program (mean 4.5). Applicants invited for interview were assessed on the quality of their responses to questions, maturity and personality. The majority of program directors agreed that a clinical elective with their program was important for consideration on their rank-order list. Program directors were neutral on their satisfaction with the selection process.

CONCLUSION: Canadian plastic surgery residency programs emphasize clinical electives with their program and letters of reference from colleagues when selecting applicants for interviews. In contrast to their American counterparts, Canadian program directors rely on clinical interactions with prospective residents in the absence of objective academic measures.

Key Words: Medical education; Plastic surgery; Residency; Selection

E ach year, plastic surgery residency training programs are tasked with recruiting and admitting the best and brightest to their specialty through a formalized residency application process. Plastic surgery remains a competitive field, with 330 applicants applying to an average of 25.5 of 61 programs in the United States integrated match (1). In 2013, Canadian plastic surgery residency programs had 57 applicants for 25 positions, and a first-choice match rate of $52 \%$, illustrating the competitive nature of the application process (2). Determining which applicants have the highest likelihood of success in residency, and would be the best fit for a residency in plastic surgery, continues to be a challenge for program directors across North America.

\section{The American experience}

We performed a systematic search of the plastic surgery literature to examine what factors are considered important in selecting candidates for residency training in plastic surgery. All available literature discussed

\section{La sélection des meilleurs et des plus intelligents : comparaison des processus de sélection des résidents aux États-Unis et au Canada}

HISTORIQUE : Il est difficile de sélectionner les candidats à la résidence en chirurgie plastique. Aux États-Unis, des mesures de réussite (notes à l'étape I de l'examen de médecine des États-Unis, rang dans la classe de la faculté de médecine et publications) sont les principaux critères de sélection des candidats à la résidence. En revanche, au Canada, les mesures de réussite de la formation en médecine sont atténuées par un système de classement réussite-échec. Il peut donc être difficile de sélectionner les résidents au sein des programmes canadiens ne disposant pas de mesures objectives de réussite.

MÉTHODOLOGIE : Les directeurs des programmes canadiens de résidence en chirurgie plastique ont reçu un sondage virtuel de 25 questions. Ils ont commenté le nombre de résidents et de candidats chaque année, les sections des candidatures (classées par ordre d'importance selon une échelle de Likert), les invitations aux entrevues, la détermination de la liste de classement et leur satisfaction à l'égard du processus de sélection.

RÉSULTATS : Dix directeurs de programmes canadiens de chirurgie plastique ont répondu au sondage (taux de réponse de 90,9\%). Les principaux volets des candidatures pour déterminer les invitations aux entrevues étaient une lettre de référence d'un plasticien (importance moyenne de 5,0 sur l'échelle de Likert), des stages cliniques facultatifs en chirurgie plastique (moyenne de 4,6) et des stages facultatifs au sein de leur programme (moyenne de 4,5). Les candidats convoqués en entrevue étaient évalués selon la qualité de leurs réponses aux questions, leur maturité et leur personnalité. La majorité des directeurs de programmes convenaient que, pour leur liste de classement, il était important d'avoir participé à un stage clinique au sein de leur programme. Le taux de satisfaction des directeurs de programmes envers le processus de sélection était neutre.

CONCLUSION : Pour sélectionner les candidats aux entrevues, les programmes canadiens de résidence en chirurgie plastique accordent plus d'importance aux stages cliniques dans leur programme et aux lettres de référence de collègues. Contrairement à leurs homologues américains, en l'absence de mesures scolaires objectives, les directeurs de programmes canadiens se fient aux interactions cliniques avec les résidents prospectifs.

the American plastic surgery match. Fourteen articles used program director surveys, applicant surveys or reviews of national matching databases. Of these articles, eight concentrated on the applicant academic and personal qualities associated with matching (Table 1) (3-11). After converting applicant academic and personal traits to a Likert scale for each survey (Tables 2 and 3), the following traits were consistently rated in the top five: Alpha Omega Alpha (AOA) Honor Medical Society membership, a clinical rotation or observership at the matched institution, United States Medical Licensing Exam (USMLE) Step I score and publication record. Rogers et al (6) identified a correlation between the number of interviews granted for plastic surgery programs and objective academic proxy measures, including AOA Honor Medical Society membership, publications, USMLE Step I score and medical class rank. These academic measures were highly rated among program directors. Seventy percent of programs with both integrated and independent streams, and 30\% 
TABLE 1

Peer-reviewed articles on resident applications and selection, American match

\begin{tabular}{|c|c|c|c|c|c|c|}
\hline Author (ref) & Year & Program & Method & Article theme & Participants & Year of survey \\
\hline $\begin{array}{l}\text { Nguyen and } \\
\text { Janis }(3)^{\star}\end{array}$ & 2012 & Independent & $\begin{array}{l}\text { Program director } \\
\text { survey }\end{array}$ & $\begin{array}{l}\text { Application components important } \\
\text { in resident selection }\end{array}$ & $\begin{array}{l}50 \text { program directors } \\
\text { (98\% response rate) }\end{array}$ & \\
\hline $\begin{array}{l}\text { Harper et al } \\
(4)^{\dagger}\end{array}$ & 2011 & Independent & Applicant survey & $\begin{array}{l}\text { Application components important } \\
\text { in resident selection }\end{array}$ & $\begin{array}{l}137 \text { plastic surgery applicants }(29.2 \% \\
\text { response rate) }\end{array}$ & 2006-2008 match \\
\hline Wood et al (5) ${ }^{\dagger}$ & 2010 & Integrated & Applicant survey & $\begin{array}{l}\text { Application components important } \\
\text { in resident selection }\end{array}$ & $\begin{array}{l}101 \text { plastic surgery applicants (48\% } \\
\text { response rate) }\end{array}$ & 2008-2009 match \\
\hline Rogers et al $(6)^{\star}$ & 2009 & Integrated & Applicant survey & $\begin{array}{l}\text { Application components important } \\
\text { in resident selection }\end{array}$ & $\begin{array}{l}139 \text { plastic surgery applicants (38\% } \\
\text { response rate) }\end{array}$ & 2006 match \\
\hline Guo et al $(7)^{\star}$ & 2008 & Both & $\begin{array}{l}\text { Single institution } \\
\text { review of residents }\end{array}$ & $\begin{array}{l}\text { Application components important } \\
\text { in resident selection }\end{array}$ & $\begin{array}{l}22 \text { independent, } 24 \text { integrated resi- } \\
\text { dents }\end{array}$ & 1999-2006 \\
\hline $\begin{array}{l}\text { LaGrasso et al } \\
(8)^{\star}\end{array}$ & 2008 & Integrated & $\begin{array}{l}\text { Program director } \\
\text { survey }\end{array}$ & $\begin{array}{l}\text { Application components important } \\
\text { in resident selection }\end{array}$ & $\begin{array}{l}15 \text { program directors } \\
\text { (75\% response rate) }\end{array}$ & \\
\hline $\begin{array}{l}\text { Janis and Hatef } \\
(9)^{\star}\end{array}$ & 2008 & Integrated & $\begin{array}{l}\text { Program director } \\
\text { survey }\end{array}$ & $\begin{array}{l}\text { Application components important } \\
\text { in resident selection }\end{array}$ & $\begin{array}{l}43 \text { program directors } \\
\text { (87.7\% response rate) }\end{array}$ & \\
\hline Higgs et al (10)* & 1992 & Integrated & $\begin{array}{l}\text { Application review } \\
\text { of all applicants to } \\
\text { plastic surgery } 1992\end{array}$ & $\begin{array}{l}\text { Application components important } \\
\text { in resident selection }\end{array}$ & $\begin{array}{l}285 \text { applications } \\
\text { (100\% response rate) }\end{array}$ & 1992 \\
\hline $\begin{array}{l}\text { Claiborne et al } \\
(11)^{\dagger}\end{array}$ & 2013 & Integrated & Applicant surgery & $\begin{array}{l}\text { Application components associated } \\
\text { with matching to plastic surgery }\end{array}$ & $\begin{array}{l}127 \text { applicants } \\
\text { (65\% response rate) }\end{array}$ & 2012 \\
\hline $\begin{array}{l}\text { Shultz et al } \\
\qquad(12)^{\ddagger}\end{array}$ & 2012 & Not specified & $\begin{array}{l}\text { Program director } \\
\text { survey }\end{array}$ & Reference letters & 28 program directors (39.4\%) & \\
\hline
\end{tabular}

*Plastic and Reconstructive Surgery; ${ }^{\dagger}$ Annals of Plastic Surgery; ${ }^{\ddagger}$ Plastic Surgery International; ref Reference

TABLE 2

Academic traits of plastic surgery applicants according to rank of importance, American match

\begin{tabular}{|c|c|c|c|c|c|c|c|c|c|}
\hline & $\begin{array}{c}\text { Harper et al, } \\
2011(4)^{\star}\end{array}$ & $\begin{array}{l}\text { Wood et al, } \\
2010(5)^{*}\end{array}$ & $\begin{array}{c}\text { Nguyen et al, } \\
2012(3)^{\dagger}\end{array}$ & $\begin{array}{l}\text { Guo et al, } \\
2008(7)^{\dagger}\end{array}$ & $\begin{array}{l}\text { LaGrasso et al, } \\
\qquad 2008(8)^{\dagger}\end{array}$ & $\begin{array}{l}\text { Rogers et al, } \\
2009(6)^{\dagger}\end{array}$ & $\begin{array}{l}\text { Rogers et al, } \\
2009(6)^{\dagger}\end{array}$ & $\begin{array}{l}\text { Janis and } \\
\text { Hatef, } \\
2008(9)^{\dagger}\end{array}$ & $\begin{array}{c}\text { Claiborne } \\
\text { et al, } \\
2013(11)^{*}\end{array}$ \\
\hline $\begin{array}{l}\text { Factor (ranked } \\
\text { according to } \\
\text { importance: } \\
1 \text { = highest) }\end{array}$ & $\begin{array}{l}\text { \% matched vs } \\
\text { unmatched inde- } \\
\text { pendent pro- } \\
\text { gram = biggest } \\
\text { difference }\end{array}$ & $\begin{array}{l}\text { \% matched } \\
\text { integrated }\end{array}$ & $\begin{array}{l}\text { Rank } \\
\text { Independent } \\
\text { program }\end{array}$ & $\begin{array}{l}\text { Mean integrated } \\
\text { vs independent } \\
\text { programs }\end{array}$ & Mean $\pm S D$ & $\begin{array}{l}\text { Correlation with } \\
\text { interview } \\
\text { invitation }\end{array}$ & $\begin{array}{l}\text { Association } \\
\text { with interview } \\
\text { invitations: } \\
\text { largest } \\
\text { difference }\end{array}$ & $\begin{array}{l}\text { Rank } \\
\text { Integrated } \\
\text { program }\end{array}$ & \\
\hline AOA Honors Society & & 2 & 7 & & 1 & & 1 & 4 & 1 \\
\hline Publications & & 1 & 6 & $\begin{array}{c}68 \text { vs } 14 \\
\text { pre-plastic } \\
\text { surgery } 6 \text { vs } 77\end{array}$ & 2 & NS & 3 & 7 & 1 \\
\hline $\begin{array}{l}\text { Letter from plastic } \\
\text { surgeon }\end{array}$ & & & 4 & & 3 & & & 6 & \\
\hline USMLE scores & & & 3 & $\begin{array}{c}\text { Step } 1 \\
235 \text { vs } 220\end{array}$ & 4 & 1 & & 3 & 1 \\
\hline ABSITE score & & & 5 & NS & & & & & \\
\hline $\begin{array}{l}\text { Letters from friend } \\
\text { or colleague }\end{array}$ & & & 2 & & 5 & & & 3 & \\
\hline $\begin{array}{l}\text { Letter of recommen- } \\
\text { dation (overall) }\end{array}$ & & & 1 & & 5 & & & 2 & \\
\hline $\begin{array}{l}\text { Medical school class } \\
\text { rank }\end{array}$ & & & & & 6 & & 2 & & \\
\hline $\begin{array}{l}\text { Rotation at your } \\
\text { institution }\end{array}$ & 1 & 2 & & & 7 & & 4 & 1 & NS \\
\hline Medical school GPA & & & & & 8 & & & 5 & \\
\hline Research performed & 3 & & 10 & $\begin{array}{c}\text { MD PhD } \\
33.3 \% \text { vs } 4.4 \%\end{array}$ & 9 & NS & 5 & 9 & 1 \\
\hline Dean's Letter & & & & & & & & 10 & \\
\hline $\begin{array}{l}\text { Medical school } \\
\text { reputation }\end{array}$ & & & & Tier 1.5 vs 2.3 & 10 & & & 3 & \\
\hline $\begin{array}{l}\text { Residency school } \\
\text { reputation }\end{array}$ & 2 & & 4 & & & & & & \\
\hline Other honors & & & 9 & & & & & & \\
\hline
\end{tabular}

*Annals of Plastic Surgery; ${ }^{\dagger}$ Plastic and Reconstructive Surgery. ABSITE American Board of Surgery In-Training Examination; AOA Alpha Omega Alpha; GPA Grade point average; NS Nonsignificant; USMLE United States Medical Licensing Examination; vs Versus 
of independent programs had a USMLE Step 1 minimum score for invitation to interview (3). Claiborne et al (11) reported that higher USMLE scores, AOA membership and greater involvement in research were the three factors significantly associated with matching to plastic surgery.

Leadership qualities, apparent maturity and personality fit were consistently ranked within the top five most influential personal attributes in selecting a plastic surgery resident. Despite this, none of these personal attributes included in program director or applicant surveys were statistically associated with matching in any study. LaGrasso et al (8) reported that program directors valued honesty most highly in their residents. Letters of recommendation ranged in importance from second to ninth overall in American program director surveys (Table 2) $(3,8,9)$. The content of the letter ranked higher in importance than being written by a friend, colleague or plastic surgeon. In one study (12), the majority of program directors believed that reference letters failed to offer a realistic method of comparing applicants and lacked objectivity. Claiborne et al (11) found no association between visiting a program on an away rotation, or having a home program and matching successfully.

Rogers et al (6) reported a positive correlation between USMLE Step 1 score and invitation to interview. Applicants with $\geq 1$ peerreviewed publication(s) received a statistically significant greater number of interviews compared with applicants with no research publications (6). An applicant's quality of responses to interview questions was listed within the top five personal traits by program directors (Table 3) $(3,8,9)$. The number of interviews was associated with matching to plastic surgery $(4,11)$. In 2011, applicants with $>10$ interviews had an $80 \%$ likelihood of successfully matching to a plastic surgery program (4). In 2012, invitations to $>8$ interviews translated into a $96 \%$ chance of matching when a single institution's applicants were surveyed (11). Janis and Hatef (9) reported a small majority of program directors agreed that a candidate's interview performance could be predictive of their performance in residency. They found that only $43.2 \%$ of program directors surveyed believed that the current methods of selecting residents was adequate in assessing the future probability of success in residency.

\section{The Canadian experience}

Recently, Nagarkar et al (13) offered advice to medical students applying to plastic surgery residency positions, emphasizing academic excellence and clinical elective experiences, which mirrors the advice frequently given to Canadian medical students pursuing competitive specialties. However, medical education in Canada has reduced the emphasis on academic competition in the past 10 years, with many medical schools eliminating class ranking, honors and academic accolades. Distinct from the American application process, Canadian residency programs are unable to use traditional academic achievements to aid in differentiating among candidates in their selection process.

To determine which factors are the most influential, we conducted a survey in which Canadian plastic surgery program directors were asked to rank the relative importance of each component of the selection process in choosing future Canadian plastic surgery residents.

\section{METHODS}

A 25-question survey was developed to determine the resident selection criteria applied by program directors for Plastic Surgery postgraduate medical residency programs in Canada (Appendix 1 [go to www.pulsus.com]). Survey review and ethics approval was obtained from the Dalhousie Health Sciences Research Ethics Board. The survey was published online using Opinio version 6.9.1 (ObjectPlanet, Norway) web-based survey software through Dalhousie University (Halifax, Nova Scotia).

The survey consisted of four areas of interest: demographic information regarding the program; application components and their utility in selecting residents; interview components, process, and importance; and satisfaction with the process of resident selection. Demographic information was collected using categorical variables.
TABLE 3

Personality traits and personal qualities of plastic surgery applicants by rank of importance, American match

\begin{tabular}{|c|c|c|c|}
\hline & $\begin{array}{c}\text { Nguyen and } \\
\text { Janis, } 2012(3)^{*}\end{array}$ & $\begin{array}{l}\text { LaGrasso et al, } \\
2008(8)^{*}\end{array}$ & $\begin{array}{c}\text { Janis and Hatef, } \\
2008(9)^{*}\end{array}$ \\
\hline $\begin{array}{l}\text { Factor (ranked by } \\
\text { importance: } \\
1=\text { highest) }\end{array}$ & $\begin{array}{l}\text { Rank Independent } \\
\text { program }\end{array}$ & Mean \pm SD & $\begin{array}{l}\text { Rank Integrated } \\
\text { program }\end{array}$ \\
\hline Leadership qualities & 7 & 1 & 4 \\
\hline Apparent maturity & 3 & 2 & 3 \\
\hline Personality "fit" & 2 & & \\
\hline Initiative & 4 & & \\
\hline Technical aptitude & 6 & & \\
\hline $\begin{array}{l}\text { Answers to } \\
\text { questions }\end{array}$ & 1 & 3 & 1 \\
\hline $\begin{array}{l}\text { Candidates interest } \\
\text { in teaching/ } \\
\text { academics }\end{array}$ & 8 & 3 & 5 \\
\hline $\begin{array}{l}\text { Attitude toward } \\
\text { questions }\end{array}$ & 5 & 4 & 2 \\
\hline $\begin{array}{l}\text { Questions that } \\
\text { candidate poses }\end{array}$ & & 5 & \\
\hline Overall appearance & 9 & 6 & 6 \\
\hline $\begin{array}{l}\text { Statement of } \\
\text { candidate's goals }\end{array}$ & & 7 & \\
\hline General knowledge & & 8 & \\
\hline
\end{tabular}

*Plastic and Reconstructive Surgery

Program directors were asked to rank the relative importance of various application components on a six-point Likert scale, in which $5=$ most or very important, $3=$ neutral, $1=$ not important and $0=$ not applicable. Interview components were discussed as binary responses for interview strategies, categorical variables for interviewer participation, and relative weighting for the importance of various information obtained within the interview. Satisfaction with the process was assessed by both categorical selection and the option for free-form comments.

The survey was distributed anonymously using e-mail through the Opinio portal to program directors of 11 Canadian plastic surgery residency training programs. Participation was voluntary and anonymous, and informed consent was obtained from the initial survey screen.

Descriptive statistics were calculated using Opinio software. Likert scale ordinal variables were assessed using frequency plots, then treated similarly to Janis and Hatef (9) by calculating the mean rank and mode (most frequent response) for each variable. Free-form comments were stored in aggregate form and any identifying details were removed.

\section{RESULTS}

The survey was distributed to 11 Canadian plastic surgery program directors in June 2014. Ten participants responded, corresponding to a survey response rate of $90.9 \%$.

Nine responding programs were five-year residency programs, with one program describing itself as longer than five years, but matching their residents through the Canadian Residency Matching System (CaRMS). Opportunity to extend training to accommodate research or graduate studies was mentioned by all responding programs. Six programs $(60 \%)$ offered residency positions to international medical graduates (IMG), one-half of which accept IMGs outside of the CaRMS process. Of the six programs hiring IMGs, five reported having $<10$ IMG applicants per year, with one institution attracting $>80$ IMG applicants per year.

The number of yearly Canadian applicants ranged between 21 and 80 applicants per program, with $70 \%$ of programs reviewing $>60$ applications per year. The number of residency positions offered through CaRMS varied by site from one (two programs) to two (five programs) to three (two programs) to four (one program) positions. 
TABLE 4

The relative importance of each application document in offering an interview to an applicant, as ranked by Canadian program directors*

\begin{tabular}{lcc}
\hline Application document & $\begin{array}{c}\text { Mean rank } \\
\text { strength } \\
\text { (10 responders) }\end{array}$ & $\begin{array}{c}\text { Most frequent } \\
\text { response (number of } \\
\text { responders) }\end{array}$ \\
\hline Letters of reference & 4.9 & $5(9)$ \\
Curriculum vitae & 4.2 & $4(6)$ \\
Application from CaRMS system & 3.7 & $5(5)$ \\
Transcript & 3.1 & $2(3)$ \\
Personal statement & 3.1 & $3(6)$ \\
MSPR/Dean's letter & 2.3 & $3(4)$ \\
\hline
\end{tabular}

*5 = most/very important, $1=$ not important, $0=$ not applicable. CaRMS Canadian Residency Matching System; MSPR Medical School Performance Record

TABLE 5

The relative importance of academic and other factors, assessed through applications, in offering interviews to applicants, as ranked by Canadian program directors*

\begin{tabular}{|c|c|c|}
\hline Factor & $\begin{array}{l}\text { Mean rank } \\
\text { strength (10 } \\
\text { responders) }\end{array}$ & $\begin{array}{c}\text { Most frequent } \\
\text { response (number } \\
\text { of responders) }\end{array}$ \\
\hline \multicolumn{3}{|l|}{ Medical education and practice } \\
\hline Clinical electives in Plastic Surgery & 4.6 & $5(7)$ \\
\hline Clinical elective at your program & 4.5 & $5(6)$ \\
\hline Grade point average & 3.6 & $5(3)$ \\
\hline Transcripts & 3.3 & $2(3)$ \\
\hline Reputation of medical school & 2.6 & $3(5)$ \\
\hline Clinical electives in other disciplines & 2.8 & $3(5)$ \\
\hline \multicolumn{3}{|l|}{ Nonmedical education } \\
\hline Graduate degree (MSc, PhD, etc) & 3.3 & $3(5)$ \\
\hline Undergraduate degree & 2.5 & $1(3)$ \\
\hline \multicolumn{3}{|c|}{ Examinations, medical licensure and declaration } \\
\hline $\begin{array}{l}\text { Prior examinations and grades } \\
\qquad(\text { LMCC, USMLE) }\end{array}$ & 2.5 & $3(6)$ \\
\hline \multicolumn{3}{|l|}{ Scholarly activities } \\
\hline Research involvement & 4.3 & $4(7)$ \\
\hline Awards and accolades & 4.0 & $4(6)$ \\
\hline Research publications & 3.9 & $4(5)$ \\
\hline Academic honors/Honors societies & 3.8 & $4(6)$ \\
\hline \multicolumn{3}{|l|}{ Additional information } \\
\hline Interests & 3.1 & $3(4)$ \\
\hline Previous work experience & 3.0 & $3(5)$ \\
\hline Previous volunteer experience & 3.0 & $3(5)$ \\
\hline \multicolumn{3}{|l|}{ Personal letter } \\
\hline Motivation & 3.9 & $4(4)$ \\
\hline Applicant personal qualities & 3.7 & $4(4)$ \\
\hline Applicant interest in plastic surgery & 3.6 & $4(3)$ \\
\hline Leadership experience & 3.6 & $4(5)$ \\
\hline Research goals & 3.2 & $4(4)$ \\
\hline Career goals & 3.0 & $3(5)$ \\
\hline \multicolumn{3}{|l|}{ Letters of reference } \\
\hline Letter of reference from plastic surgeon & 5.0 & $5(10)$ \\
\hline Who says it & 4.9 & $5(9)$ \\
\hline What the letter says & 4.8 & $5(8)$ \\
\hline Letter of reference from other & 3.6 & $5(3)$ \\
\hline
\end{tabular}

*5 = most/very important, 1 = not important, $0=$ not applicable. LMCC Licentiate of the Medical Council of Canada; USMLE United States Medical Licensing Examination
TABLE 6

Interview components and their importance in selecting medical student applicants for residency in Canadian plastic surgery programs*

\begin{tabular}{lcc}
\hline & $\begin{array}{c}\text { Mean rank } \\
\text { strength } \\
\text { (10 responders) }\end{array}$ & $\begin{array}{c}\text { Most frequent } \\
\text { response } \\
\text { (number of } \\
\text { responders) }\end{array}$ \\
\hline Quality of responses to questions & 4.8 & $5(8)$ \\
Maturity & 4.5 & $4(5)$ \\
Personality & 4.5 & $5(7)$ \\
Leadership potential & 3.9 & $4(5)$ \\
Interest in research and academics & 3.8 & $3(4)$ \\
Applicant experience & 3.3 & $4(5)$ \\
Appearance & 2.8 & $3(4)$ \\
Questions the candidate asks & 2.8 & $3(5)$ \\
\hline
\end{tabular}

*5 = most/very important, 1 = not important, 0 = not applicable

Application component rankings

The mean ranking of each document included in medical student applications is listed in Table 4. Program directors listed letters of reference as the most important document when choosing medical students for interview. They also listed the curriculum vitae and the applications from the CaRMS system as important; however, there was variation among program directors when ranking the importance of transcripts (range 1 to 5), personal statements (range 2 to 5 ) and the Dean's letter from the applicant's medical school (range 1 to 4 ).

Each document contains a variety of applicant's academic and clinical experience as well as personal qualities frequently discussed in their personal letters. Program directors ranked the relative importance of these various applicant experiences and qualities contained in their applications (Table 5). The most important factors determining an invitation to interview for a plastic surgery residency position included letters of reference from a plastic surgery (mean 5.0 points), who the reference letter was written by (mean 4.9 points) and what the reference letter said about the applicant (mean 4.8 points). Clinical electives in plastic surgery (mean 4.6 points) and at their program ranked very highly in importance by program directors (mean 4.5 points). Academic success including the applicants' research involvement, awards and accolades, and research publications ranked highly, as did the expression of personal motivation by applicants in their personal letters.

\section{Interviews}

Six of the 10 responding program directors $(60 \%)$ offered between 16 and 20 interviews per year to Canadian applicants for CaRMS positions (range 10 to 25). All responders interviewed $<10$ IMG applicants per year. Nine of the 10 programs included clinical scenario testing in the interview, and one program utilized art or sculpting tests during their interview.

Interviews were primarily conducted by committees, which included the program director $(90 \%)$, representative faculty $(90 \%)$ and residents $(100 \%)$. One program included all faculty in their interview process. In $70 \%$ of programs, a committee composed of core faculty and residents generated the final rank-order list. One program did not involve residents in the final rank-order list, and two others used a standardized attempt to stratify candidates, reducing the influence of a single member on the final rank-order. One institution's program director was the final determinant of rank-order list. Rank-order lists ranged from seven to 18 applicants.

Asked to rank the importance of various interview components in the assessment of applicants, program directors consistently ranked the quality of responses to questions (mean 4.8 points), maturity (mean 4.5 points) and the personality of the applicant (mean 4.5 points) as very important factors in determining rank-order position (Table 6). 


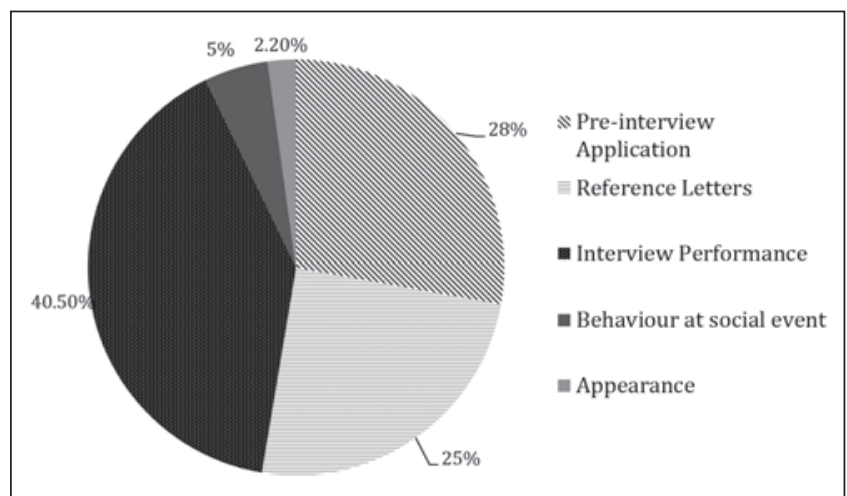

Figure 1) The contribution of each application component to a candidate's rank-list position in the Canadian plastic surgery match

Common themes featured in program director comments included the importance of personality, proven work ethic, judgment, and the subjective assessment of whether the candidate would be easy to work with for a five-year residency. Teamwork, strong work ethic, maturity, respectfulness with multidisciplinary teams, humour and social stability were listed by program directors as personality traits desirable in their residents. Nearly all program directors stressed the importance of a candidate's performance in clinical electives and through their observation in rotations with their program or through reference letters.

\section{Rank-order lists}

When determining candidate rank-order positions, programs weighted the interview most heavily (mean $40.5 \%$, range $20 \%$ to $65 \%$ ), followed by the preinterview application (mean $28.0 \%$, range $10 \%$ to $55 \%$ ) and letters of reference (mean $25.0 \%$, range $5 \%$ to $60 \%$ ) (Figure 1 ). The majority of program directors $(80.0 \%)$ agreed that a visiting rotation with their program was very important to be considered for a position on their rank-order list. Program directors varied in their opinions whether a candidate's interview is indicative of their performance during residency, and whether the quality of their residents has been consistently predicted by their position on the rank-order list (Figure 2). When asked whether they were satisfied by the current selection process, program directors were clustered around neutral. Comments included the difficulty in differentiating among many qualified candidates when selecting residents, and the lack of objective and validated tools in assessing medical student applicants.

\section{DISCUSSION}

In the American plastic surgery matching process, measures of academic success including USMLE Step I score and medical class rank were consistently ranked among the top five criteria, along with AOA Honors Medical Society membership and the number of publications. In surveys of applicants, these academic factors were positively associated with interview invitation. Higher USMLE scores, AOA Honor Medical Society membership, and the number of completed research projects were the only three factors found in our literature review to be significantly associated with matching to plastic surgery.

Program directors of residency programs across Canada do not have standardized objective measures of academic achievement on the majority of the applicants. Current Canadian medical education has reduced the emphasis on competition and academic ranking over the past 10 years. Many schools have abandoned class-rank lists and honors achievements, shifting the formal medical evaluations to academic pass-fail and practical clinical evaluations. Standardized examinations including the Licentiate of the Medical Council of Canada (LMCC) Part I occur after residency selection. Instead, invitation to interview must be based on self-reported achievements by the applicants, a program's personal experience with the applicant and clinical evaluations including letters of reference.

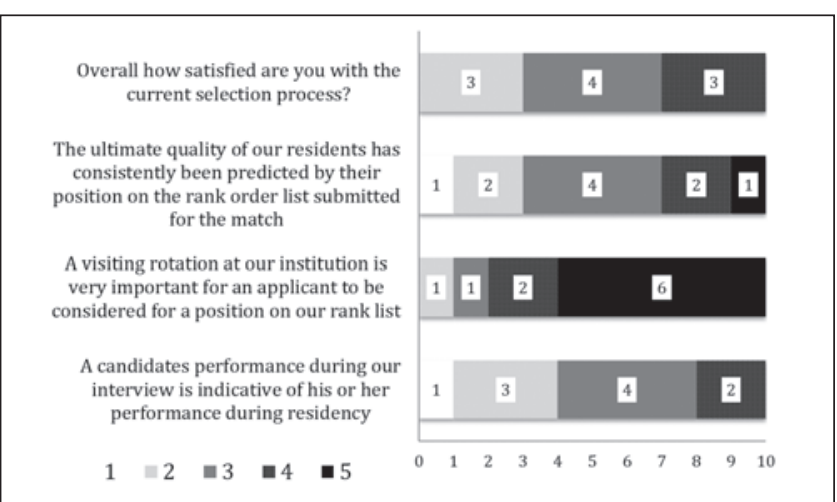

Figure 2) Opinions of Canadian program directors on the reliability of rank-order lists, and their satisfaction with the process of resident selection. ( $1=$ not accurate, $5=$ very accurate $)$

A unique feature of the Canadian plastic surgery matching process was the importance of clinical electives with a program in being offered an interview or ranking high on the rank-order list. With only 11 plastic surgery training programs in the country, program directors and faculty often have the chance to work with candidates from across the country before the submission of CaRMS applications. The working relationships that are formed between applicants and programs during the clinical elective stage appear to have a lasting impact in their match success, both for interviewing with a program and in the form of reference letters distributed across the country. Although programs benefit from meeting applicants in a clinical elective setting, this may pose a financial challenge for applicants. The burden of travel and housing costs may prevent applicants from lower socioeconomic backgrounds from pursuing visiting clinical electives to the same extent as colleagues of higher socioeconomic standing. Whether the number of plastic surgery electives and the financial costs associated with travelling impact the match success of Canadian plastic surgery applicants has not been studied.

Canadian plastic surgery residency training programs rely primarily on personal experience with candidates through clinical electives, and reference letters from trusted colleagues when choosing applicants for interviews. Performance during the interview, including answers to questions, their clinical judgment and the expression of the candidate's personality and maturity, play an important role in determining the position of the candidate on the rank-order list. The interview was weighted most heavily by program directors in their final ranking of candidates in the Canadian matching process. The consensus from the American literature appears to also emphasize the importance of interpersonal skills and personality attributes including honesty, usually assessed throughout the course of the interview, as markers of a successful resident. Three American studies asked program directors to rank the importance of interview performance in residency selection. One study listed interview performance as the most important determinant of rank position (3), while two studies found that a candidate's history of leadership abilities, maturity and attitude evidenced through academic achievements were more important than their actual interview responses $(8,9)$.

Overall, Canadian program directors varied in their satisfaction with the process of resident selection in plastic surgery. None of the program directors reported that they were very satisfied with the process, and $55 \%$ of programs have had residents placed on probation for academic or ethical reasons in the past 10 years. Janis and Hatef (9) found that only $43.2 \%$ of American program directors surveyed believed that the current methods of selecting residents was adequate in assessing the future probability of success in residency. The lack of satisfaction with the process includes the difficulty in consistently and concretely assessing the potential of applicants to become strong residents within the limitations of applications and short interviews. Canadian plastic surgery program directors commented 
on the subjectivity of our current assessments and the difficulty in establishing consistency year-to-year in their own programs. From the American general surgery literature, residents requiring remediation frequently have lower USMLE Step I scores compared with their peers, and lower in-training exam scores $(14,15)$; however, further analysis by Yaghoubian et al (14) found that USMLE Step I scores were not predictive of resident attrition. USMLE Step I minimum scores have been shown to be associated with passing rates in the American Board of Surgery examinations $(15,16)$. By comparison, there are currently no benchmarks in plastic surgery residency training that correlate with future success on the American Board of Plastic Surgery examinations or the Canadian Royal College examinations.

In the absence of objective academic measures, Canadian plastic surgery programs rely on assessments made during clinical interactions with prospective medical students when choosing which applicants to interview and rank for residency positions. A national initiative within

\section{REFERENCES}

1. Association of American Medical Colleges. Electronic Residency Application Service. Table 41: Residency Applicants of U.S. Medical School Graduates by Specialty, 2008-2013. 2013.

2. Canadian Resident Matching Service (CaRMS). CaRMS 2013 R-1 Match Report. 2013.

3. Nguyen AT, Janis JE. Resident selection protocols in plastic surgery: A national survey of plastic surgery independent program directors. Plast Reconstr Surg 2012;130:459.

4. Harper JG, Given KS, Pettitt B, Losken A. The independent plastic surgery match. An in-depth analysis of the applicants and process. Ann Plast Surg 2011;66:568-71.

5. Wood JS,David LS. Outcome analysis of factors impacting the plastic surgery match. Ann Plast Surg 2010;64:770-4.

6. Rogers CR, Gutowski KA, Munoz-del Rio, et al. Integrated plastic surgery residency applicant survey: Characteristics of successful applicants and feedback about the interview process. Plast Recontr Surg 2009;123:1607.

7. Guo L, Friend J, Kim E, Lipsitz S, Orgill DP, Pribaz J. Comparison of quantitative educational metrics between integrated and independent plastic surgery residents. Plast Reconstr Surg 2008;122:972.

8. LaGrasso JR, Kennedy DA, Hoehn JG, Ashruf S, Przybyla AM. Selection criteria for the integrated model of plastic surgery residency. Plast Reconstr Surg 2008;121:121e. plastic surgery to develop validated tools for applications and interviews may improve the reliability and transparency of the resident selection process as we choose our future colleagues. Before developing these tools, plastic surgery programs may want to improve the accessibility of clinical electives with their programs to assess a larger number of potential candidates.

AUTHOR CONTRIBUTIONS: EM Krauss - search strategy, data analysis, manuscript preparation; M Bezuhly - manuscript preparation; JG Williams - research question, manuscript preparation. Presented at the Canadian Society of Plastic Surgery meeting, May 28 to June 1, Calgary, Alberta, June 2013.

DISCLOSURES: The authors have no financial disclosures or conflicts of interest to declare.

9. Janis JE, Hatef DA. Resident selection protocols in plastic surgery: A national survey of plastic surgery program directors. Plast Reconstr Surg 2008;122:1929.

10. Higgs PE, Edwards D, White D, Weeks PM. Plastic surgery applicants in 1992. Plast Reconstr Surg 1993;91:1355.

11. Claiborne JR, Crantford JC, Swett KR, David LR. The plastic surgery match; predicting success and improving the process. Ann Plast Surg 2013;70:698-703.

12. Shultz K, Mahabir RC, Song J, Verheyden CN. Evaluation of the current perspectives on letters of recommendation for residency applicants among plastic surgery program directors. Plast Surg Int 2012;2012:728981.

13. Nagarkar P, Pulikkottil B, Patel A, Rohrich RJ. So you want to become a plastic surgeon? What you need to do and know to get into a plastic surgery residency. Plast Reconstr Surg 2013;131:419-22.

14. Yaghoubian A, Galante J, Kaji A, et al. General surgery resident remediation and attrition. Arch Surg 2012;147:829.

15. Virgilio C, Yaghoubian A, Kaji A, et al. Predicting performance on the American board of surgery qualifying and certifying examinations. Arch Surg 2010;145:852.

16. Shellito JL, Osland JS, Helmer SD, Chang FC. American Board of Surgery examinations: Can we identify surgery residency applicants and residents who will pass the examinations on the first attempt? Am J Surg 2010;199:216. 